\title{
TRAFFIC: WHY WE DRIVE THE WAY WE DO (AND WHAT IT SAYS ABOUT US)
}

\author{
Tom Vanderbilt
}

\section{NISSAN DISTINGUISHED KEYNOTE LECTURE}

The talk will present findings and implications from the New York Times bestselling book "Traffic: Why We Drive the Way We Do (and What It Says About Us)," including the dynamics of traffic flow, the social interactions of drivers, the perceptual illusions and cognitive biases to which humans behind the wheel are prone, the relationship between the built environment and our behavior, among other aspects of this complex, yet overlooked, everyday activity. There will be a particular focus on the role of science in effecting behavioral change.

Tom Vanderbilt writes on design, technology, science, and culture, among other subjects, for many publications, including Wired, Slate, The London Review of Books, Gourmet, The Wall Street Journal, Men's Vogue, Artforum, The Wilson Quarterly, Travel and Leisure, Rolling Stone, The New York Times Magazine, Cabinet, Metropolis, and Popular Science. He is contributing editor to the design magazines I.D. and Print, and contributing writer of the popular blog Design Observer. His most recent book is the New York Times bestseller Traffic: Why We Drive the Way We Do (and What It Says About $U$ s), published by Alfred A. Knopf. He is the author of two previous books: Survival City: Adventures Among the Ruins of Atomic America (Princeton Architectural Press, 2002), an offbeat architectural travelogue of the nation's secret Cold War past; and The Sneaker Book (The New Press, 1998), a cultural history of the athletic shoe. 